\title{
Determining Handle Position for Boxes Based on Psychophysical and Physiological Studies on Male Workers
}

\author{
Boy Nurtjahyo Muchamad, Maya Arlini Puspasari, Erlinda Muslim, and Aisyah Iadha Nuraini
}

\begin{abstract}
Handle on the container used in industry has an important role to reduce injuries while doing the activity manual materials handling (MMH). handle design in most industries in Indonesia is usually located on top or no handle. Therefore, this study is conducted to determine the handle position on the box. The method used is the design of experiment (DOE) based on psychophysical and physiological criteria for male workers. A psychophysical criterion refers to the borg scale for rating perceived exertion (RPE), whereas the physiological criterion refers to the heart rate. RPE and heart rate is a dependent variable, while the independent variables used were four box sizes, nine handling positions, and three handle positions on the box. Ten subjects from industrial workers performed 27 combinations for one day during four day. The results of this study indicate that a significant factor influencing psychophysical criteria are 3 main effects, while the physiological criteria just 2 main effects, handle position and box size; based on psychophysical criteria, the handle position on top has a higher RPE values than other positions; and based on physiological criteria, the handle position on top produces a higher heart rate than the other positions.
\end{abstract}

Index Terms - Design of experiment, handle position, manual material handling, physiological, psychophysical.

\section{INTRODUCTION}

Nowadays, although the technology and the use of machines is growing, human intervention in some jobs that require convenience and flexibility still has a big role in industry. For example, the loading and unloading activities of product get into the pallet and truck in the manufacturing industry. The product loading activity is often referred as Manual Materials Handling (MMH). Manual Material Handling is an activity consisting of lifting, carrying, bending, and twisting motion on the torso which is a major cause of spinal cord injury and other diseases [1], [2]. In Indonesia, workers who perform MMH activities still occur due to the nature of many types of jobs that are flexible and inexpensive. Workers who normally perform the work are male workers.

One example of MMH activities is the process of transporting the products which are usually packaged in a cardboard box. The use of box often used as a container that can hold a variety of products and facilitate the transport

Manuscript received April 7, 2014; revised May 25, 2014. This work was supported by Ergonomics Centre Laboratory in Universitas Indonesia.

Boy Nurtjahyo Muchamad, Maya Arlini Puspasari, and Erlinda Muslim are with the Department of Industrial Engineering Universitas Indonesia, Indonesia (e-mail: boymoch@eng.ui.ac.id, maya.arlini@yahoo.com, erlinda@eng.ui.ac.id).

Aisyah Iadha Nuraini is with NTUST, Indonesia (e-mail: aisyah.iadha.n@gmail.com). process. A number of designs are raised to protect the product in the box and also packing/unpacking system. Design in Indonesia based on observations without a handle or the position is at the top. Existing size is also varies depending on the type of product that is packaged so there are no specific standards in determining the size of the box and also the determination of the required handle. Therefore, the research discussed about this topic is needed.

Based on previous studies related to the carry activity, it is known there are 3 factors that affect the maximum load capacity: the individual, the workers, occupational activity, and environmental factors [3]. Examples of worker factors are age, gender, and experiences of individuals [4]. Examples of work activity factors are carrying distance, weight, frequency, position while carrying, shape objects, and the materials used [4]. Examples of environmental factors are the room temperature and the room while doing the [4]. In addition, there are studies that divide into 5 factors which affect the physical stress. There are the physical and physiological, characteristics when do the MMH activities, the characteristics of the object, the position of lifting (methods of handling materials), spatial aspects of MMH, and environmental factors [5]. These factors need to be considered in carrying out related research activities MMH.

According to Chaffin (1987), Sanders and McCormick (1992), Mital et al (1993), Waters et al., (1993), Ciriello (2005), based on factors that are studied, the characteristics of object lifted have a significant effect on stress level of biomechanical, physiological, and psychophysical activities that accompany the MMH [5]-[10]. One of the characteristics of the object studied is the influence of whether there is a handle for the load-carrying capacity. In addition, it states that the existence of the handle will provide a higher level of security and a low pressure compared to no handle when carrying [11]. This study also suggested conducting further research on the position of the handle that can provide comfort and have a low stress [11]. Therefore, based on knowledge gained associated with the studies outlined above, there is no been research related to handle position in terms of psychophysical and physiological methods. This method is valid and used by the studies related to MMH for 3 decades [3].

The objectives to be achieved in this study was to determine the factors that influence the physiological and psychophysical criteria in determining the position of the handle on the box and determine the position of the handle in accordance with the approach of psychophysical and physiological for male workers. 


\section{METHOD}

\section{A. Determining the Factors}

Based on research conducted by Jung and Jung (2010), the author uses 3 parameters for continuing advice from these studies by different methods that is psychophysical and physiological [5], which are: Box Size (4 levels: $30 \times 30 \times 30$ $\mathrm{cm}, 40 \times 40 \times 40 \mathrm{~cm}, 50 \times 50 \times 50 \mathrm{~cm}$ and $60 \times 60 \times 60 \mathrm{~cm})$, handle position (top, middle, and bottom), and lifting position (floor position, the position of the knuckle height $74 \mathrm{~cm}$, and the position of the breast height $110 \mathrm{~cm}$ ).

\section{B. Determining Response Variable}

Response variables studied were heart rate, Rating Perceived exertion (RPE), and user preferences using Likert scale 5.

\section{Design of Experiment}

Experimental design used was a randomized complete block design. This design to control variability arising from non-uniform experimental units that need to be done block. On this design, all blocks contain all treatment. Randomization was performed on each block.

Randomization was performed in this study is randomizing the order of trials of 108 existing combinations. This randomization using a random number that is in that excel further sorted with the greatest value was as a first treatment to the smallest value as a treatment done last.

Repetition (replication) is a repetition of the basic treatment given to the experimental units. Replication of this research is the number of subjects entering the study. The number of subjects who began the study as many as 10 men who have experienced the heavy work and in good health, mean replication in this study as much as 10 times.

\section{Research Tool}

The following instruments and equipment are required in the study are: 1) questionnaire; 2) boxes used in prototype (can be seen in Fig. 1); 3) Place placement customized box with vertical distance measurement to be used, which is 74 $\mathrm{cm}$ and $110 \mathrm{~cm}$; 4) Loads used in this study purports square tiles measuring $20 \mathrm{~cm} \mathrm{x} 20 \mathrm{~cm}$ with a weight of 500 grams of ceramics; 5) Omron scales that can digitally measure the body weight, body mass index, percent body fat, muscle mass percent, biological age, and the number of calories needed; 6) Digital sphygmomanometer is used to measure pulse and blood pressure; 7) Hand Dynamometer to measure the strength of the subject's hand to experiment; 8) Push Pull Dynamometer function to measure the tensile strength of the subject, and 9) Heart Rate Monitor Tool to record heart rate during the experiments.

\section{E. Data Acquisition Procedures}

Here is the detail steps of primary data collection conducted in this study:

1) Candidates who are interested in the subject to follow the experiment were collected in a single day and given explanations. Each candidate has the right subjects chose to participate in the study or not. There is no coercion in this study. For those candidates who have been willing to follow the subject of this study, they will sign a promissory note that will follow to complete the study. Prospective subjects who have signed letters of intent will be asked to fill out personal data and medical history.

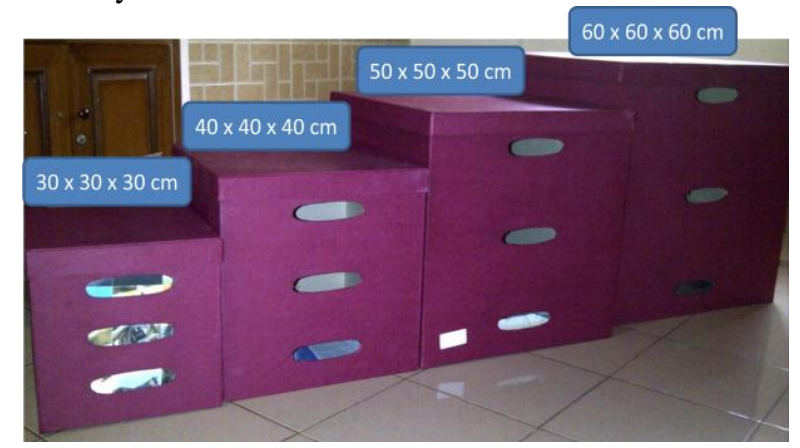

Fig. 1. Prototype of the box.

2) Next, measurements were taken to see the body weight, height, knuckle height, shoulder height, blood pressure, heart rate, hand grip strength, and tensile strength.

3) If the subject has met the criteria and were willing to follow the research, will be determined time for data retrieval research. In the study of data collection, the subject should not do strenuous activity (body burden).

4) At the time of the study prior to data collection, subjects who had been re-elected will be given an explanation of the steps and procedures that must be performed during the study. Explanations include:

- Explanation of safe lifting procedures which can be seen in Fig. 2

- Explanation and simulation on how to fill or answer Borg Scale and Likert 5 [12]

- Warm up about 10-15 minutes in advance in order to improve the accuracy of measurement of the heart rate

- The combination takes approximately 1.5 minutes to 2 minutes. Each completed a combination; each respondent will rest for 1 minute to 2 minutes.
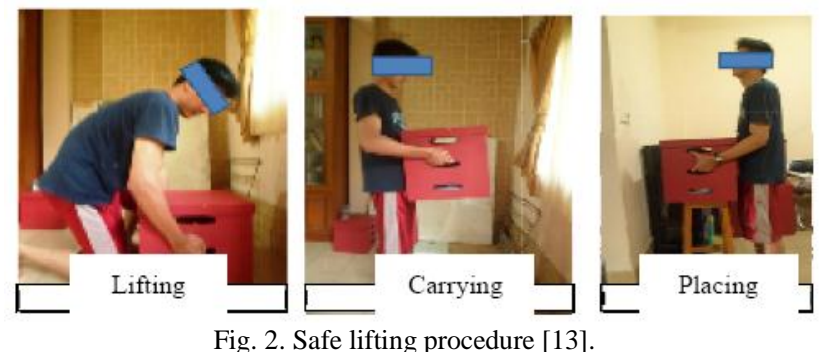

Fig. 2. Safe lifting procedure [13]

\section{F. Hypothesis Testing}

Hypothesis testing is done to see the influence of the main factors on heart rate, RPE, and Likert-5 and also the interaction between factors. Equation model used is the model three way because the number of factors used in this study, there are 3 factors. The following equation models in this study:

$$
\begin{aligned}
y_{i j k l}= & \mu+A_{i}+B_{j}+C_{k}+(A B)_{i j}+(A C)_{i k}+ \\
& (B C)_{j k}+(A B C)_{i j k}+\varepsilon_{i j k l}
\end{aligned}
$$

with $i=1,2, \ldots, \mathrm{a}, j=1,2, \ldots, b, k=1,2, \ldots, c$, dan $\mathrm{l}=1,2, \ldots$, $n$ 
TABLE I: EXAMPLE OF RPE DATA

\begin{tabular}{|c|c|c|c|c|c|c|c|c|c|c|c|}
\hline \multirow{3}{*}{$\begin{array}{l}\text { Box } \\
\text { Size }\end{array}$} & \multirow{3}{*}{$\begin{array}{l}\text { Handle } \\
\text { Position }\end{array}$} & \multirow{3}{*}{$\begin{array}{l}\text { Classifi } \\
\text { cation }\end{array}$} & \multicolumn{9}{|c|}{ Lifting Position } \\
\hline & & & $\begin{array}{l}\text { Floor-F } \\
\text { loor }\end{array}$ & $\begin{array}{l}\text { Floor- } \\
\text { Knuckl } \\
e\end{array}$ & $\begin{array}{l}\text { Knuckl } \\
e \text {-Floor }\end{array}$ & $\begin{array}{l}\text { Knисkl } \\
\text { e-Knис } \\
\text { kle }\end{array}$ & $\begin{array}{l}\text { Floor-S } \\
\text { houlder }\end{array}$ & $\begin{array}{l}\text { Should } \\
\text { er-Floo } \\
\mathrm{r}\end{array}$ & $\begin{array}{l}\text { Knuckl } \\
e \text {-Shou } \\
\text { lder }\end{array}$ & $\begin{array}{l}\text { Should } \\
\text { er-Knu } \\
\text { ckle }\end{array}$ & Shoulder-Shoulder \\
\hline & & & $K_{1}$ & $K_{2}$ & $K_{3}$ & $K_{4}$ & $K_{5}$ & $K_{6}$ & $K_{7}$ & $K_{8}$ & $K_{9}$ \\
\hline \multirow{6}{*}{$\begin{array}{c}30 \times 30 \\
\times 30 \\
\mathrm{~cm}\end{array}$} & Top & Mean & 13.4 & 12.9 & 13.3 & 13.2 & 14.3 & 13.8 & 14 & 14.1 & 13.7 \\
\hline & & Std & 1.07 & 1.66 & 2.06 & 1.48 & 1.16 & 1.14 & 1.56 & 1.60 & 2.00 \\
\hline & Middle & Mean & 12.8 & 13.2 & 13.7 & 13.2 & 13.9 & 13.4 & 13.7 & 13 & 13.3 \\
\hline & & Std & 1.81 & 1.55 & 2.12 & 1.42 & 1.14 & 0.99 & 1.23 & 1.70 & 2.04 \\
\hline & Under & Mean & 13.1 & 12.6 & 13.0 & 12.1 & 13.5 & 13.1 & 12.9 & 13.5 & 13.5 \\
\hline & & $S t d$ & 1.20 & 1.78 & 1.83 & 1.66 & 0.85 & 1.45 & 2.18 & 1.43 & 0.97 \\
\hline
\end{tabular}

TABLE II: ANOVA RESULT OF RPE

\begin{tabular}{|c|l|l|l|l|l|l|l|}
\hline Source & Factor & $\begin{array}{c}\text { Sum of } \\
\text { Square }\end{array}$ & Df & $\begin{array}{l}\text { Mean } \\
\text { Square }\end{array}$ & Computed $F$ & $p$-Value & Information \\
\hline \multirow{4}{*}{ Main Effect } & Box Size & 136,79 & 3 & 45,598 & 22,339 & $0,000^{* * *}$ & Significant \\
\cline { 2 - 8 } & Handle Position & 270,73 & 2 & 135,369 & 66,320 & $0,000^{* * *}$ & Significant \\
\cline { 2 - 8 } & Lifting Position & 140 & 8 & 17,500 & 8,574 & $0,000^{* * *}$ & Significant \\
\hline \multirow{5}{*}{$\begin{array}{l}\text { Two-way } \\
\text { interaction }\end{array}$} & $\begin{array}{l}\text { Box Size*Handle } \\
\text { Position }\end{array}$ & 40,00 & 6 & 6,667 & 3,266 & $0,003^{* * *}$ & Significant \\
\cline { 2 - 8 } & $\begin{array}{l}\text { Box Size* Lifting } \\
\text { Position }\end{array}$ & 32,94 & 24 & 1,373 & 0,672 & 0,881 & No Significant \\
\cline { 2 - 8 } & $\begin{array}{l}\text { Handle } \\
\text { Position*Lifting } \\
\text { Position }\end{array}$ & 28,58 & 16 & 1,786 & 0,875 & 0,599 & No Significant \\
\hline \multirow{2}{*}{$\begin{array}{l}\text { Three-way } \\
\text { Interaction }\end{array}$} & $\begin{array}{l}\text { Box Size*Handle } \\
\text { Positio*Lifting } \\
\text { Position }\end{array}$ & 32,81 & 48 & 0,684 & 0,335 & 1,000 & No Significant \\
\hline
\end{tabular}

TABLE III: HEART RATE DATA

\begin{tabular}{|c|c|c|c|c|c|c|c|c|c|c|c|}
\hline \multirow{3}{*}{$\begin{array}{l}\text { Box } \\
\text { Size }\end{array}$} & \multirow{3}{*}{$\begin{array}{l}\text { Handle } \\
\text { Position }\end{array}$} & \multirow{3}{*}{$\begin{array}{l}\text { Classifi } \\
\text { cation }\end{array}$} & \multicolumn{9}{|c|}{ Lifting Position } \\
\hline & & & $\begin{array}{l}\text { Floor-F } \\
\text { loor }\end{array}$ & $\begin{array}{l}\text { Floor-K } \\
\text { nuckle }\end{array}$ & $\begin{array}{l}\text { Knuckle } \\
\text {-Floor }\end{array}$ & $\begin{array}{l}\text { Knuckle } \\
\text {-Knuckl } \\
e\end{array}$ & $\begin{array}{l}\text { Floor- } \\
\text { Shoul } \\
\text { der }\end{array}$ & $\begin{array}{l}\text { Shoulde } \\
\text { r-Floor }\end{array}$ & $\begin{array}{l}\text { Knuckle- } \\
\text { Shoulder }\end{array}$ & $\begin{array}{l}\text { Shoulde } \\
\text { r-Knuck } \\
\text { le }\end{array}$ & $\begin{array}{l}\text { Shoul } \\
\text { der-Sh } \\
\text { oulder }\end{array}$ \\
\hline & & & $K_{1}$ & $K_{2}$ & $K_{3}$ & $K_{4}$ & $K_{5}$ & $K_{6}$ & $K_{7}$ & $K_{8}$ & $K_{9}$ \\
\hline \multirow{6}{*}{$\begin{array}{l}30 \times 30 \\
\times 30 \mathrm{~cm}\end{array}$} & Top & Mean & 94.6 & 95.7 & 93.4 & 95.3 & 96.2 & 96.8 & 93.6 & 97.6 & 96.9 \\
\hline & & Std & 6.98 & 8.14 & 5.27 & 7.80 & 8.48 & 6.61 & 7.32 & 8.53 & 8.49 \\
\hline & Middle & Mean & 91.2 & 94.5 & 93.1 & 95.1 & 93.1 & 95.8 & 94.3 & 94.5 & 97 \\
\hline & & Std & 5.98 & 7.53 & 4.79 & 8.46 & 6.82 & 7.13 & 8.34 & 5.54 & 8.16 \\
\hline & Under & Mean & 94.1 & 92.4 & 93.1 & 94.2 & 95.1 & 92.1 & 94.6 & 96.1 & 95.5 \\
\hline & & Std & 6.74 & 7.89 & 6.23 & 6.80 & 7.23 & 7.75 & 6.77 & 6.54 & 6.04 \\
\hline
\end{tabular}

TABLE IV: ANOVA RESULT OF HEART RATE

\begin{tabular}{|c|c|c|c|c|c|c|c|}
\hline Source & Factor & $\begin{array}{l}\text { Sum of } \\
\text { Square }\end{array}$ & $D f$ & $\begin{array}{l}\text { Mean } \\
\text { Square }\end{array}$ & $\begin{array}{c}\text { Computed } \\
F\end{array}$ & $p$-Value & Information \\
\hline \multirow{3}{*}{ Main Effect } & Box Size & 7249,86 & 3 & 2416,6 & 37,85 & $0,000 * * *$ & Significant \\
\hline & Handle Position & 740,85 & 2 & 370,42 & 5,80 & $0,003 * * *$ & Significant \\
\hline & Lifting Position & 584,83 & 8 & 73,10 & 1,14 & 0,330 & No Significant \\
\hline \multirow{3}{*}{$\begin{array}{l}\text { Two-way } \\
\text { interaction }\end{array}$} & Box Size*Handle Position & 91,52 & 6 & 15,25 & 0,24 & 0,964 & No Significant \\
\hline & Box Size* Lifting Position & 525,1 & 24 & 21,88 & 0,34 & 0,999 & No Significant \\
\hline & $\begin{array}{l}\text { Handle Position*Lifting } \\
\text { Position }\end{array}$ & 293,95 & 16 & 18,37 & 0,29 & 0,997 & No Significant \\
\hline $\begin{array}{l}\text { Three-way } \\
\text { Interaction }\end{array}$ & $\begin{array}{l}\text { Box Size*Handle } \\
\text { Position*Lifting Position }\end{array}$ & 573,14 & 48 & 11,94 & 0,19 & 1,000 & No Significant \\
\hline
\end{tabular}


TABLE V: ANOVA RESULT FOR LIKERT SCALE

\begin{tabular}{|c|c|c|c|c|c|c|c|}
\hline Source & & $\begin{array}{l}\text { Sum of } \\
\text { Square }\end{array}$ & $D f$ & Mean Square & Computed F & p-Value & Information \\
\hline \multirow{3}{*}{ Main Effect } & Box Size & 21,87 & 3 & 7,291 & 9,040 & $0,000 * * *$ & Significant \\
\hline & Handle Position & 386,37 & 2 & 193,184 & 239,509 & $0,000 * * *$ & Significant \\
\hline & Lifting Position & 41,63 & 8 & 5,204 & 6,452 & $0,000 * * *$ & Significant \\
\hline \multirow{3}{*}{$\begin{array}{l}\text { Two-way } \\
\text { interaction }\end{array}$} & $\begin{array}{l}\text { Box Size*Handle } \\
\text { Position }\end{array}$ & 58,3 & 6 & 9,716 & 12,046 & $0,000 * * *$ & Significant \\
\hline & $\begin{array}{l}\text { Box Size* Lifting } \\
\text { Position }\end{array}$ & 11,06 & 24 & 0,461 & 0,571 & 0,952 & No Significant \\
\hline & $\begin{array}{l}\text { Handle Position*Lifting } \\
\text { Position }\end{array}$ & 26,35 & 16 & 1,647 & 2,042 & $0,009 * * *$ & Significant \\
\hline $\begin{array}{l}\text { Three-way } \\
\text { Interaction }\end{array}$ & $\begin{array}{l}\text { Box Size*Handle } \\
\text { Position*Lifting } \\
\text { Position }\end{array}$ & 19,52 & 48 & 0,407 & 0,504 & 0,998 & No Significant \\
\hline
\end{tabular}

\section{RESULTS AND DISCUSSION}

\section{A. Rating Perceived Exertion (RPE)}

Table I shows the average of the RPE obtained. RPE were divided into 3 groups on the position of the handle and 9 positions in each group appointment.

To identify why RPE differ on three factors, namely the position of the handle, the position of the appointment, and the size of the box it was a three-way ANOVA. Table II shows the results of a three-way ANOVA.

\section{B. Heart Rate}

Table III shows the average of the heart rate is obtained. To identify why different heart rate on three factors, namely the position of the handle, the position of the appointment, and the size of the box it was a three-way ANOVA. Table IV shows the results of a three-way ANOVA.

\section{Likert Scale}

Data processing for Likert scale is based on research by Jung and Jung (2010) [5]. Table V shows the results of ANOVA analyze were conducted for the data Likert scale.

\section{Rating Perceived Exertion (RPE)}

Based on the results in Table II, the significant variables need a Duncan Test to determine the real differences of each level / degree of factors. Duncan's test results show that the size of $30 \times 30 \times 30 \mathrm{~cm}, 40 \times 40 \times 40 \mathrm{~cm}$, and $50 \times 50 \times 50$ $\mathrm{cm}$ are in the same subset that means are not significantly differed, where size $60 \times 60 \times 60 \mathrm{~cm}$ is in different subset, so it is significantly differed. Thus it can be stated that the RPE is the highest in the $60 \times 60 \times 60 \mathrm{~cm}$ box size.

Duncan test is then performed on the handle position factor on RPE values. Duncan test results indicate that all real handle position differed significantly. The handle which required higher energy is in the top, while the smallest is in the bottom.

Duncan test is then performed on the lifting position on RPE values. Duncan test results showed that the position of the knuckle-knuckle (or positions $K_{4}$ ) produces the lowest value of RPE. Positions are significantly differed at the $K_{9}$ position (height chest-chest height) and $K_{5}$ (floor-chest height). In both these positions require higher RPE compared to other positions.

In addition to Duncan test, also tests for normality and homogeneity of RPE value. From both the results of the test, the normality and homogeneity assumption are fulfilled.

\section{E. Heart Rate}

Duncan's test results show that the size of $30 \times 30 \times 30 \mathrm{~cm}$ and $60 \times 60 \times 60 \mathrm{~cm}$ are significantly differed, whereas the size $40 \times 40 \times 40 \mathrm{~cm}$ and $50 \times 50 \times 50 \mathrm{~cm}$ are in the same subset size means it is no differed significantly. Thus it can be stated that the highest heart rate is at $60 \times 60 \times 60 \mathrm{~cm}$, while the lowest in the size of $30 \times 30 \times 30 \mathrm{~cm}$. High heart rate showed higher energy expenditure than others.

Duncan test is then performed on the handle position factor of heart rate each respondent. Duncan test results showed that the position of the handle on the top significantly differed compared to the middle or bottom. Top handle requires higher heart rate, while the smallest is in the bottom and middle positions.

Duncan test is then performed on the lifting position factor on heart rate value. Duncan test results showed that the Knuckle-position floor (or position $K_{3}$ ) has a low heart rate. Positions are significantly differed at the $K_{9}$ position (height chest-chest height) and $K_{5}$ (floor-chest height). At both positions had greater heart rate and requires considerable energy compared to other positions.

In addition to Duncan test, normality and homogeneity test are conducted to measure heart rate. From both the results of the test, the normality and homogeneity assumption are fulfilled.

\section{F. Likert 5}

The factor of box size that have significantly differed there are two sizes $30 \times 30 \times 30 \mathrm{~cm}$ and $60 \times 60 \times 60 \mathrm{~cm}$. User preference is perceived by the subject that is lighter in size 30 $\times 30 \times 30 \mathrm{~cm}$, whereas the heavier size is $60 \times 60 \times 60 \mathrm{~cm}$. Furthermore for grip position, all variables are significantly differed. The position on the grip feels heavier in the bottom position. The third factor is the lifting position. Factors that have a significant difference are the position of the appointment of $K_{5}, K_{9}$, and $K_{4}$. Position appointment $K_{4}$ (knuckle-knuckle) is perceived as the most comfortable position.

However, Likert 5 data are not normally distributed and should be using non-parametric statistics in its processing. Therefore, the Kruskall-Wallis test was used to see the results of the analysis of the real difference each treatment. Hypothesis on Kruskall-Wallis test, namely:

$H_{0}$ : All combinations were not significantly differed

$H_{1}$ : All combinations were significantly differed

Based on the test results, the p-value $(0.000)<5 \%$ alpha, then reject $H_{0}$, which means all combinations were significantly differed. 


\section{G. Covariate Analysis for Load}

The load has a significant effect on the RPE values, because it is known that the p-value of load is $(0.000)<5 \%$ alpha. The load also has a significant effect on the value of heart rate. On the results obtained in the analysis of covariates obtained load effects on heart rate, it is known that the p-value of load is $(0.000)<5 \%$ alpha, then reject $\mathrm{H}_{0}$. Based on the results obtained in the analysis of covariates regarding load effects on the value of Likert 5 , note that the p-value $(0.113)>5 \%$ alpha, then accept $H_{0}$. Therefore it can be concluded that the load does not have a significant effect on the value of the value obtained Likert 5 .

\section{CONCLUSION}

Based on psychophysical criteria, factors that significantly influence the value of the RPE are 3 main factors (the position of the handle, the position of the appointment, and the size of the box). In addition to these three factors, there was an interaction between the factors size box with handle position which means a change in the level of one factor may result in significant changes to the value of RPE. The larger the box size, the effort given by the subjects also increased. The position of the handle which gives a greater effort is in the grip position.

Based on physiological criteria, factors which significantly affect heart rate are 2 main factors (the position of the handle and the size of the box). The larger the size, the heart rate produced by the subject also increases. For position handle based on physiological criteria, the position of the handle in the middle and bottom position gives lower heart rate than position in the top. This suggests that the lower and middle position gives a lower energy level than the position of the handle at the top.

\section{REFERENCES}

[1] C. D. Wickens, S. E. Gordon, and Y. Liu, An Introduction to Human Factors Engineering, New York: Longman, 1998.

[2] M. M. Ayoub and A. Mital, Manual Materials Handling, London: Taylor and Francis, 1989.

[3] H. Lu and F. Aghazadeh, "Psychophysical determination and modeling of load carrying capacity," International Journal of Industrial Ergonomics, vol. 13, no. 1, pp. 51-65, 1994.

[4] S. P. Wu, "Psychophysical determined 1-h load carrying capacity of chinese female," International Journal of Industrial Ergonomics, vol. 36, no. 10, pp. 891-899, 2006.

[5] H. S. Jung and H. S. Jung, "A survey of the optimal handle position for boxes with different sizes and manual handling positions," Applied Ergonomics, vol. 41, no. 1, pp. 115-122, 2010.

[6] D. B. Chaffin, "Manual materials handling and the biomechanical basis for prevention of low back pain in industry," American Industrial Hygene Association Journal, vol. 48, no. 12, pp. 989-998, 1987.
[7] M. S. Sanders and E. J. M. Cormick, Human Factors in Engineering and Design Seventh Edition, New York: McGraw-Hill, 1992.

[8] A. Mital, A. Nicholson, and M. Ayoub, A Guide to Manual Materials Handling, London: Taylor and Francis, 1993.

[9] T. Waters, V. P. Anderson, A. Garg, and L. Fine, "Revised NIOSH equation for the design and evaluation of manual lifting tasks," Ergonomics, vol. 36, no. 7, pp. 749-776, 1993.

[10] V. M. Ciriello, "The effects of box size, vertical distance, and height on lowering tasks for female industrial workers," International Journal of Industrial Ergonomics, vol. 35, no. 9, pp. 857-863, 2005.

[11] C. G. Drury, "Handles for manual materials handling," Applied Ergonomics, vol. 11, no. 1, pp. 35-42, 1980.

[12] G. Borg, Borg's Perceived Exertion and Pain Scales, Human Kinetics, 1998.

[13] NIOSH. Work Practices Guide for Manual lifting, Cincinnati, OH: DHHS (NIOSH) Publication, 1981.

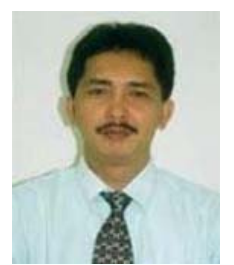

Boy Nurtjahyo Muchamad was born in Jakarta on 3 November 1955. He started his higher education mechanical engineering, Universitas Indonesia before he obtained his master degree in Wayne State University in USA. Currently, he is a lecturer in Department of Industrial Engineering, Universitas Indonesia. His interest of research is in the field of human factors and ergonomics, organizational aspect of industry, and computer modeling and simulation.

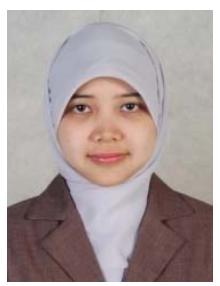

Maya Arlini Puspasari was born in Jakarta on 22 March 1988. She was graduated from Industrial Engineering, Universitas Indonesia in 2009. Then, she obtained her master degree from double degree of National Taiwan University of Science and Technology (NTUST) and Universitas Indonesia, her majoring in Industrial Engineering in 2011. She is a lecturer in Department of Industrial Engineering, Her research interest is in the field of human factors, traffic safety,

and product design.

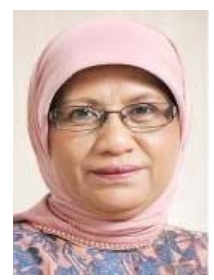

Erlinda Muslim was born in Bukittinggi on 28 October 1960. She was graduated from Mechanical Engineering, Bandung Institute of Technology in 1984. Then, she obtained her Master Degree from Universiti Teknologi Malaysia in 1992. Currently, she is a lecturer in Department of Industrial Engineering, Her research interest is in the field of ergonomics and product design.

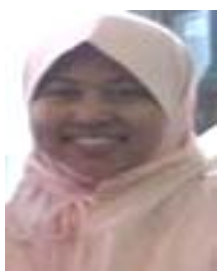

Aisyah Iadha Nuraini was born in Jakarta, 29 June on 1990. She was graduated from Industrial Engineering, Universitas Indonesia in 2013. Currently, she is a master degree student in NTUST, majoring Industrial Management. Her research interest is about ergonomics and safety. 